\title{
Estrogen and Interleukin-1 $\beta$ regulation of trophinin, osteopontin, cyclooxygenase-1, cyclooxygenase-2, and interleukin-1ß system in the porcine uterus
}

\author{
F.J. White', E.M. Kimball', G. Wyman', D.R. Stein'2, J.W. Ross', \\ M.D. Ashworth ${ }^{2}$ and R.D. Geisert $t^{4}$ \\ 'Cameron University, Lawton, OK; ${ }^{2} O$ klahoma State University, Stillwater, OK; \\ ${ }^{3}$ lowa State University, Ames, IA; ${ }^{4}$ University of Missouri, Columbia, MO, USA
}

Embryonic loss during early gestation limits litter size in swine production. Failure of the conceptus to attach properly to the uterine surface may contribute to the high rate of embryonic loss observed in swine. Attachment to the uterine surface is a highly synchronized event that requires precise communication between the expanding conceptus and endometrial tissue. Conceptus attachment to the uterine surface includes upregulation of adhesion molecules at the maternal/fetal interface for attachment as well as a pregnancy specific inflammatory response. Trophinin and osteopontin are cell adhesion molecules that may function in initial attachment between conceptus trophectoderm and uterine luminal epithelium of the pig and human. Leukocytes infiltrate the endometrium during implantation, and the pro-inflammatory cytokines Cyclooxygenase (COX)- 1 and COX-2 are expressed in human and pig endometrium during pregnancy, where they are proposed to regulate conceptus implantation and uterine angiogenesis. Interleukin-1 $\beta$ (IL-1 $\beta$ ) increases during implantation in the mouse, human and pig and may regulate uterine inflammatory cytokines. Estrogen also controls uterine events necessary for attachment and implantation of the mouse and pig conceptus and may act in synergy with IL-1 $\beta$ to prepare the uterus for the implanting embryo. Furthermore, trophinin expression was induced by IL-1 $\beta$ in human endometrial cells, and uterine osteopontin expression is regulated by estrogen in the pig and mouse. The objective of the current study was to evaluate the hypotheses that estrogen regulates the uterine inflammatory response induced by IL-1 $\beta$ during the establishment of pregnancy.

Cyclic gilts were treated with corn oil or estradiol cypionate $(5 \mathrm{mg})$ on Day 11 of the estrous cycle. On Day 12, gilts were subjected to mid-ventral laparotomy and uterine horns were randomly infused with either saline or porcine IL-1 $\beta(15 \mu \mathrm{g})$. Uterine horns were removed at $4 \mathrm{~h}$ and $36 \mathrm{~h}$ post-infusion ( 4 gilts/trt/sampling periods) and endometrial mRNA was quantified by quantitative RT-PCR.

Estrogen did not influence $(P>0.1)$ concentrations of endometrial COX-1 and COX-2 mRNA; however, IL-1 $\beta$ increased $(P=0.01)$ endometrial COX-2 mRNA by 3.5 fold and tended $(P=0.06)$ to increase COX-1 mRNA by 2.5 fold 4 h post infusion. Cyclooxygenase- 1 and COX-2 regulate uterine prostaglandin secretion, which is essential to normal implantation and pregnancy in pigs (Kraeling et al. 1985). Cyclooxygenase-2 null mice are infertile and fail to implant; however, implantation is not impeded in the Cox-1 null mouse (Lim et al. 1997). Although the conceptus induces uterine COX-2 expression at implantation sites, estrogen did not increase COX-2 mRNA in ovariectomized mice which is true in our pig study (Chakraborty et al. 1996). Furthermore, IL-1 $\beta$ regulates ovulation in mice through COX-2 and prostaglandin production (Davis et al. 1999). We hypothesize that conceptus IL-1 $\beta$ regulates uterine prostaglandin secretion by increasing endometrial COX-2. Prostaglandins regulate angiogenesis 
and the conceptus may increase uterine vascularity through IL-1 $\beta$ induced COX- 2 .

The elongating porcine conceptus secretes IL-1 $\beta$ on Day 12 of pregnancy during conceptus attachment and maternal recognition of pregnancy, and this correlates with endometrial Interleukin-1 receptor type 1 and interleukin receptor accessory protein gene expression suggesting conceptus interleukin upregulates its own endometrial receptors (Ross et al. 2003). In the current study, IL-1 $\beta$ increased $(P=0.05)$ its own expression by 3.5 fold and tended $(P=.08)$ to increase Interleukin-1 receptor type 1 by 2.5 fold; however, estrogen not IL-1 $\beta$ increased $(P<0.05)$ interleukin receptor accessory protein $(2.5$ fold increase). Similarly, IL$1 \beta$ increased Interleukin-1 receptor type 1 in human endometrial stromal and glandular cells (Soloff et al. 2004). Interleukin-1 $\beta$ and estrogen differentially regulated uterine interleukin receptors; therefore their combined effects may alter the endometrial response to IL-1 $\beta$ during implantation.

Endometrial osteopontin and trophinin were increased $(P<0.05)$ at $36 \mathrm{~h}$ but not $4 \mathrm{~h}$ after estrogen treatment. Estrogen treated gilts had 11.3 fold greater OPN and 3.6 fold greater trophinin endometrial mRNA than gilts treated with corn oil. Trophinin mRNA and protein are located at the maternal/fetal interface during implantation of pigs, mice, and humans (Suzuki et al. 2000, Nakano et al. 2003, Sugihara et al. 2008). Uterine trophinin is increased by estrogen in mice but IL-1 $\beta$ in human endometrial cells (Sugihara et al. 2008), suggesting expression is pigs and mice are controlled by similar mechanism which differs from humans. The fact that OPN and trophinin receptors are located on conceptus trophectoderm suggests a role in attachment and communication at the maternal/fetal interface. We hypothesize that IL-1 $\beta$ and estrogen secretion by the pig conceptus differentially modulates uterine expression of COX-1, COX-2, trophinin, osteopontin, and the interleukin- $1 \beta$ system providing an inflammatory environment that is essential to establish pregnancy.

\section{References}

Chakraborty I, Das SK, Wang I, \& Dey SK 1996 Developmental expression of the cyclo-oxygenase-1 and cyclo-oxygenase- 2 genes in the peri-implantation mouse uterus and their differential regulation by the blastocyst and ovarian steroids. Journal of Molecular Endocrinology 16 107-122.

Davis BI, Lennard DE, Lee CA, Tiano HF, Morham SG, Wetsel WC \& Langenbach R 1999 Anovulation in Cyclooxygenase-2-Deficient Mice Is Restored by Prostaglandin $\mathrm{E}_{2,}$ and interleukin-1 $\beta$. Endocrinology 140 2685-2695.

Kraeling RR, Rampacek GB \& Fiorello NA 1985 Inhibition of pregnancy with indomethacin in mature gilts and prepubertal gilts induced to ovulate. Biology of Reproduction 32 105-110.

Lim H, Paria BC, Das SK, Dinchuk JE, Langenbach R, Trzaskos IM \& Dey SK 1997 Multiple female reproductive failures in cyclooxygenase 2 -deficient mice. Cell 91 197-208.

Nakano S, Kishi H, Ogawa H, Yasue H, Okano A \& Okuda K 2003 Trophinin is expressed in the porcine endometrium during the estrous cycle. Journal of Reproduction and Development 49 127-134.
Ross JW, Malayer JR, Ritchey IW \& Geisert RD 2003 Characterization of the interleukin-1 B system during porcine trophoblastic elongation and early placental attachment. Biology of Reproduction 69 1251-1259.

Soloff MS, Cook DL, Jr, Jeng Y-J \& Anderson CD 2004 In situ analysis of interleukin-1-induced transcription of cox-2 and il-8 in cultured human myometrial cells. Endocrinology 145 1248-1254.

Sugihara K, Kabir-Salmani M, Byrne J, Wolf DP, Lessey B, Iwashita M, Aoki D, Nakayama I \& Fukuda MN 2008 Induction of trophinin in human endometrial surface epithelia by CGbeta and IL-1 1 beta. FEBS Letters 582 197-202.

Suzuki N, Nadano D, Paria BC, Kupriyanov S, Sugihara K \& Fukuda MN 2000 Trophin expression in the mouse uterus coincides with implantation and is hormonally regulated but not induced by implanting blastocysts. Endocrinology $1414247-4254$. 